\title{
ESFERA \\ JURÍDICA \\ EM DESTAQUE: \\ UM OLHAR SOBRE \\ O GÊNERO \\ PETIÇÃO INICIAL
}

ESFERA JURÍDICA EN DESTAQUE: UNA MIRADA AL GÉNERO DEMANDA INICIAL

JUDICIAL SPHERE IN FOCUS: A LOOK ON INITIAL PETITION AS A GENRE

Jokasta Neves Pires*

Márcia Helena de Melo Pereira**

Universidade Estadual do Sudoeste da Bahia

RESUMO: Com base na importância que o Direito possui para a sociedade, uma vez que, de uma forma ou de outra, encontra-se presente na história dos indivíduos, é relevante conhecermos melhor os gêneros discursivos da esfera jurídica. Nesse sentido, nosso objetivo é investigar um desses gêneros, a petição inicial, tendo em vista seus aspectos temáticos, composicionais e estilísticos. Para tanto, recolhemos 25 exemplares de petições iniciais no site oficial do Tribunal de Justiça de Bahia (TJ/BA), escritas por advogados diferentes. Em relação ao conceito de gêneros discursivos, utilizamos, como fundamento teórico, a Filosofia da Linguagem de Bakhtin (2003). Na seara jurídica, valemo-nos de teóricos como Didier (2015), de manuais de Direito e do Código de Processo Civil brasileiro (CPC) - (Lei n 13.105/2015). A partir de nossas análises, constatamos que a petição inicial é um gênero rígido, bastante padronizado e com poucas possibilidades de entradas individuais.

PALAVRAS-CHAVE: Esfera jurídica. Gêneros discursivos. Petição Inicial.

RESUMEN: En función de la importancia que el Derecho tiene para la sociedad, una vez que, de una forma u otra, se encuentra presente en la historia de los individuos, es importante conocer mejor los géneros discursivos de la esfera jurídica. En ese sentido,

\footnotetext{
* Mestranda do Programa de Pós-Graduação em Linguística da Universidade Estadual do Sudoeste da Bahia (UESB). Possui graduação em Direito pela mesma Universidade. E-mail: jokastapires@hotmail.com.

** Doutora em Linguística Aplicada pela Universidade Estadual de Campinas. Professora do Departamento de Estudos Linguísticos e Literários e docente do quadro permanente do Programa de Pós-Graduaça em Linguística, ambos da Universidade Estadual do Sudoesteda Bahia (UESB). E-mail: marciahelenad@yahoo.com.br.
} 
nuestro objetivo es investigar uno de esos géneros, la demanda inicial, considerando sus aspectos temáticos, compositivos y estilísticos. Para ello, recogemos 25 ejemplares de demandas iniciales en el sitio oficial del Tribunal de Justicia de Bahía (TJ / BA), escritos por diversos abogados. Respecto al concepto de géneros discursivos, utilizamos, como fundamento teórico, la Filosofía del Lenguaje de Bakhtin (2003). En el ámbito jurídico, nos valemos de teóricos como Didier (2015), de manuales de Derecho y del Código de Proceso Civil brasileño (CPC) - (Ley nº13.105/2015). A partir de nuestros análisis, constatamos que la demanda inicial es un género rígido, bastante estandarizado y con pocas posibilidades de entradas individuales.

PALABRAS CLAVE: Esfera jurídica. Géneros discursivos. Demanda inicial.

ABSTRACT: Drawing on the importance that Law has to society, sinceitis present in everyman's history, it is relevant to better understandthediscursive genres of the judicial sphere. In this respect, our aim is to investigate one of these genres, the initial petition, taking into account its thematic aspects. For this purpose, we collected 25 copies of initial petitions on the official website of Bahia Court of Justice (CJ/BA), from various lawyers. In relation to the concept of discursive genres, we adopt as theoretical basis, Bakhtin's Philosophy of Language (2003). On the judicial field, we follow Didier (2015), Law textbooks and the Brazilian Civil Procedure Code (CPC) - (Law n ${ }^{\circ}$ 13.105/2015)., Our analysis revealed that the initial petition is a rigid genre, highly standardized and with little possibilities for individual entries.

KEYWORDS: Judicial sphere. Discursive genres. Initial petition.

\section{IINTRODUÇ̃̃O}

Com base na teoria de Bakhtin (2003), a área jurídica configura-se como uma esferasocioideológica de comunicação humana e, assim, possui também seus gêneros discursivos, os quais merecem ser investigados, haja vista a influência do Direito na vida dos indivíduos. Nesse sentido, nosso propósito, neste artigo, é investigar um desses gêneros, a petição inicial, buscando lançar sobre ela um olhar do ponto de vista dos estudos da linguagem.

A petição inicial é utilizada para iniciar o processo judicial cível. Nela se encontram as bases que darão sustentação a tudo mais que será discutido e desenvolvido ao longo da marcha processual. É na petição inicial que o advogado sustenta, de forma escrita, toda a história narrada por seu cliente e faz a subsunção do fato à norma, ou seja, mostra que os acontecimentos por ele narrados ferem algum dispositivo de lei, gerando um dano ao seu cliente, dano esse que precisa ser reparado. Nossa investigação ocorrerá a partir dos três pilares do gênero propostos por Bakhtin (2003), a saber: conteúdo temático, estilo e estrutura composicional. Para alcançar nossos objetivos, recolhemos 25 exemplares de petições iniciais no site oficial do Tribunal de Justiça de Bahia (TJ/BA), escritas por advogados diferentes.

Sabemos que nem sempre os gêneros jurídicos conseguem ser claros como deveriam, dificultando o trabalho não apenas daqueles que fazem parte da área, mas também a vida da população. Diante do rebuscamento e tecnicismo que norteiam a linguagem com a qual se realizam as práticas jurídicas atuais, procuramos desenvolver a presente pesquisa, que buscou responder ao seguinte questionamento: a linguagem jurídica é de difícil compreensão, tendo em vista os aspectos inerentes à construção dos seus textos?

Buscando responder a essa pergunta, nosso trabalho almeja conhecer um pouco mais sobre esse gênero tão essencial da seara jurídica, qual seja: a petição inicial, a fim de torná-lo mais compreensível para todos que, direta ou indiretamente, são ou serão impactados por ele. Pretendemos realizar uma investigação voltada para questões relativas à construção do texto, aos sentidos produzidos e à caracterização léxico-gramatical desse gênero. Ou seja, buscamos demonstrar como certas características linguísticas (tipos de orações, estrutura temática etc.) caracterizam as práticas desenvolvidas pelos profissionais do Direito por meio da linguagem, tendo em vista o gênero petição inicial, e a dificuldade que tais características geram para a realização do processo de compreensão textual

Com base na importância que o Direito possui para a sociedade, já que se trata “[...]de um conjunto de regras obrigatórias que garante a convivência social, que regula a conduta do homem na sociedade, que coloca um mínimo de regra ou de norma a ser seguida pela sociedade[...]" (BRANDÃO, 2010), é necessário que a população à qual ele se destina seja capaz de compreender os

Pires \& Pereira| Esfera jurídica em destaque: um olhar sobre o gênero petição inicial 
textos jurídicos, que, neste trabalho, se referem aos textos que transitam ou são produzidos por aqueles indivíduos que atuam na órbita do Poder Judiciário, haja vista ser, dentre os três poderes do Estado Democrático de Direito, aquele que possui a incumbência de garantir a aplicabilidade da lei.

Para a realização da tarefa de averiguarmos um dos gêneros próprios dessa esfera, utilizamos, como fundamento teórico, o filósofo russo Bakhtin (2003), cuja filosofia da linguagem concebe a língua como interação. Para o autor, a linguagem é dialógica porque interage com o passado, o presente e o futuro ao ser posta em funcionamento.

Buscamos embasamento teórico também no Código de Processo Civil Brasileiro (CPC - Lei n 13.105/2015), que apresenta os requisitos constitutivos da petição inicial. Abordamos, ainda, teóricos do Direito. Utilizamos nomes da doutrina jurídica referentes à processualística civil, tais como: Fredie Didier (2015), autor baiano de diversas obras na área da disciplina jurídica denominada "Direito Processual Civil". Além dele, recorremos a outros nomes do Direito Processual Civil, como Marinoni, Arenhart e Mitidiero (2015), para compreendermos e explicarmos ao leitor a petição inicial do ponto de vista jurídico.

Para melhor organização da pesquisa, as seções estão assim dispostas: primeiramente, o estudo trata das questões relativas aos gêneros discursivos na perspectiva de Bakhtin (2003), com base nos três pilares dos gêneros por ele propostos. Na próxima seção, apresentamos a petição inicial, explicando-a com base no CPC e doutrina jurídica. Segue-se com a apresentação das questões metodológicas e, em seguida, com a seção de resultados. Ao final, faz-se uma seção de considerações finais.

\section{FUNDAMENTAÇ̃̃ TEÓRICA}

A compreensão do conceito de gênero discursivo postulado por Bakhtin (2003) é fundamental para a realização das nossas análises. Além de realizarmos essa discussão, pontuaremos, nesta seção, as considerações relativas ao Direito Processual Civil acerca do gênero petição inicial.

\subsection{OS GÊNEROS DO DISCURSO}

Para Bakhtin (2003), quando usamos a língua, nos pautamos na interação sociodiscursiva construída e em construção no ato de enunciação. Assim, a linguagem só tem razão de ser no seu uso, por meio da interação social entre os sujeitos. Bakhtin (2003, 2011) entende que fora do enunciado ou enunciação (linguagem em uso marcada pela interação social e pela ideologia) tem-se uma visão reducionista da linguagem.

Para Bakhtin (2003), a língua, ao ser posta em funcionamento, segue padrões ritualísticos. Tais padrões são fruto do embate social construído na interação mediante a história. Assim, todo ser humano, enquanto participante de esferas da atividade humana, é atravessado pelas mais diversas formas de enunciados, construídos no tempo e espaço por intermédio da interação. Esses enunciados são únicos e concretos, porém Bakhtin (2011) informa que cada esfera de utilização da língua "[...] elabora seus tipos relativamente estáveis de enunciados [...]", aos quais ele chamou gênero do discurso.

Os gêneros do discurso são compostos por três pilares, postulados pelo autor como sendo: o conteúdo temático, a estrutura composicional e o estilo. Para Bakhtin, esses pilares não estão isolados entre si. Apesar de podermos fazer um estudo parcialmente separado de cada um, eles estão entrelaçados, formando um todo. Portanto, não faz sentido nem é possível entendê-los de modo estanque, já que todos eles cooperam para a realização do "projeto enunciativo", como ressalta Ribeiro (2010). Ainda de acordo com a autora, o conceito de gênero deve levar em consideração as circunstâncias em que o texto foi construído, seja sob a perspectiva dos sujeitos sociais que se inter-relacionam na situação de comunicação, seja sob a ótica da temática proposta ou dos aspectos do meio social e suas implicações na escolha dos recursos linguísticos e discursivos.

Vejamos como Bakhtin (2003) entende cada um desses pilares, iniciando a discussão pelo conteúdo temático. 
O pilar conteúdo temático não pode ser entendido como mero assunto a ser tratado pelo gênero. Sobre essa questão, Ribeiro (2010) salienta que "[...] o conteúdo temático, longe de ser somente o assunto focado na enunciação, é um dos eixos dos quais o locutor, diante de sua movência, da sua plasticidade, vale-se para se manter socialmente coerente [...]" (RIBEIRO, 2010, p. 58). Podemos entender o conteúdo temático como o conjunto de dizeres que se consolidaram no curso da interação social, em uma esfera da atividade comunicativa. É importante ressaltar que, para Bakhtin (2003), todos os pilares dos gêneros são também elementos relativamente estáveis, os quais permitem marcas de individualidade ${ }^{1}$ dos sujeitos presentes na enunciação.

O segundo pilar é a estrutura composicional. Ela representa o arranjo composicional próprio de cada gênero discursivo, revelando sua forma de se exteriorizar. Segundo o teórico russo, ela se refere a "[...] tipos de construção do conjunto, tipos de acabamento [...]" (BAKHTIN, 2011, p. 266). Ribeiro (2010), por sua vez, assegura que à estrutura composicional “[...] cumpre a função de integrar, de sustentar e ordenar as particularidades do gênero [...]" (RIBEIRO, 2010, p. 60). Ainda nas palavras da linguista, a estrutura composicional está relacionada ao "[...] aspecto por assim dizer técnico da realização do gênero, contribuindo para identificá-lo e distingui-lo diante de outros gêneros [...]" (RIBEIRO, 2010, p. 60). Portanto, podemos perceber que a unidade em estudo contribui para que um gênero seja diferenciado de outro, uma vez que trata da forma como o gênero se apresenta organizado - ou seja, as partes que ele, visivelmente, possui.

O terceiro pilar é o estilo. Sobre ele, Bakhtin (2003) relata que “[...] todo estilo está indissoluvelmente ligado ao enunciado e às formas típicas de enunciados, ou seja, aos gêneros do discurso [...]" (BAKHTIN, 2003, p. 265). Aqui, o teórico mostra a necessidade de o estilo ser considerado sob a perspectiva do gênero e, assim, da enunciação. Isso porque, apesar de o "[...] estilo dizer respeito aos recursos lexicais, fraseológicos e gramaticais da língua [...]" (RIBEIRO, 2010, p. 61) presentes no gênero, não se deve tomá-lo como aspectos meramente gramaticais ou lexicais usados nos gêneros, mas é preciso integrá-lo na ótica do projeto da enunciação, ou seja, na interação, na esfera de atividade humana à qual está incorporado. De acordo com Bakhtin (2011), "[...] onde há estilo há gênero [...]" (BAKHTIN, 2011, p. 268) e "[...] mudanças no estilo implicam diretamente nas mudanças dos gêneros do discurso [...]" (PRADO; PEREIRA; PEREIRA, 2016, p. 04). Porém, como é inerente à teoria enunciativa, apesar do papel determinante das construções ideológicas na comunicação verbal, há sempre lugar para a individualidade dos sujeitos.

Na perspectiva bakhtiniana, o estilo se apresenta em duas modalidades, quais sejam: o estilo individual e o estilo do gênero. Ribeiro (2010, p. 59) afirma que "[...] o estilo individual é resultante da singularidade do sujeito enunciador, das escolhas particularizadas do ser na dinâmica discursiva [...]"; já no que se refere ao estilo do gênero afirma que "[...] é fruto da convergência dos usos linguísticos, textuais e discursivos reiterados em um dado contexto enunciativo [...]" (RIBEIRO, 2010, p. 59). É significativo relembrar as palavras de Bakhtin (2003) quando informa que nem todos os gêneros são igualmente favoráveis a refletir a individualidade do enunciador. Em contrapartida, alguns gêneros seriam mais propícios a revelar a individualidade daquele que enuncia. Bakhtin (2011) também nos indica que os gêneros mais propícios a manifestar a individualidade do falante são os literários, uma vez que "[...] o estilo individual integra diretamente o próprio edifício do enunciado, é um dos seus objetivos principais [...]” (BAKHTIN, 2011, p. 265). Já gêneros mais oficiais, como aqueles que representam espécies de documentos públicos, são mais padronizados, permitindo pouca entrada do falante no que se refere à sua individualidade.

O que podemos dizer quanto ao gênero petição inicial? Como são seus pilares? Seria esse gênero mais propício à expressão da individualidade do sujeito enunciador? Entretanto, antes de investigarmos tal gênero e respondermos a esses questionamentos, precisamos averiguar o que o Código de Processo Civil brasileiro (Lei no 13.105/2015) nos diz sobre ele.

\subsection{O QUE O CÓDIGO DE PROCESSO CIVIL DIZ SOBRE A PETIÇÃO INICIAL}

A petição inicial é o instrumento que inaugura o processo judicial. De acordo com Didier (2015, p. 547), "[...] o processo nasce com a propositura da demanda [...]" e "[...] a demanda considera-se proposta na data em que a petição inicial foi protocolada [...]" (CPC, art. 312). A petição inicial, no entanto, não pode ser confundida com a demanda. Segundo Didier (2009), "[...] a relação entre a

${ }^{1}$ Mesmo o plano individual, na filosofia da linguagem de Bakhtin, tem caráter social, uma vez que tanto a personalidade individual quanto a atividade mental de tipo coletivista são socialmente estruturadas (RIBEIRO, 2010). 
petição inicial e a demanda é a mesma que se estabelece entre forma e conteúdo. Do mesmo modo que o instrumento de um contrato não é o contrato, a petição inicial não é a demanda [...]" (DIDIER, 2009, p. 407). Assim, podemos dizer que a demanda é a causa, é a situação conflituosa que se pretende resolver nos órgãos judiciais. Essa demanda só se materializa no âmbito judicial, ou seja, só passa a existir quando a petição inicial (forma por meio da qual se inicia a demanda na Justiça) é protocolada no devido órgão judicial. A demanda se manifesta, inicialmente, com a petição inicial e continua a se desenvolver nos atos processuais posteriores.

No processo judicial cível, a petição inicial pode ser oral ou escrita. Nosso enfoque é na petição inicial que já chega ao Poder Judiciário, obrigatoriamente, na forma escrita ${ }^{2}$. Assim, essa petição inicial tem seus requisitos previstos no artigo 319 do CPC. Vejamos a redação desse artigo:

\begin{abstract}
A petição inicial indicará: I - o juízo a que é dirigida; II - os nomes, os prenomes, o estado civil, a existência de união estável, a profissão, o número de inscrição no Cadastro de Pessoas Físicas ou no Cadastro Nacional da Pessoa Jurídica, o endereço eletrônico, o domicílio e a residência do autor e do réu; III - o fato e os fundamentos jurídicos do pedido; IV - o pedido com as suas especificações; V - o valor da causa; VI - as provas com que o autor pretende demonstrar a verdade dos fatos alegados; VII - a opção do autor pela realização ou não de audiência de conciliação ou de mediação (Artigo 319, CPC) (BRASIL, 2015).
\end{abstract}

Além desses requisitos da petição inicial, podemos também apresentar outros que estão previstos em artigos, como exemplo 320 , 330 e 332, do mesmo dispositivo legal. Em nosso trabalho, interessa-nos investigar os requisitos apresentados no artigo 319 do CPC, uma vez que são eles que constituem a petição inicial, fazendo dela um gênero textual.

A seguir, apresentamos os aspectos metodológicos que seguimos para a realização da investigação aqui proposta.

\title{
3 ASPECTOS METODOLÓGICOS
}

Para realizarmos a investigação que aqui propomos, seria necessário termos acesso a exemplares de petições iniciais diversas e confeccionadas por advogados diferentes. Nesse sentido, conseguiríamos comparar os modelos e chegar a conclusões mais precisas acerca dos pilares do gênero em estudo. Por isso, recolhemos, no site oficial do Tribunal de Justiça da Bahia (TJ/BA), 25 petições iniciais. Esse número nos permitiu visualizar uma quantidade grande de petições iniciais, dando-nos suporte para capturarmos características do gênero e alcançarmos nossos objetivos.

Com nosso acervo em mãos, iniciamos o trabalho de análise, elaborando planilhas que nos permitiram condensar os significados e particularidades de cada petição inicial analisada. Assim, buscamos destacar/dissecar os termos técnicos utilizados nos textos e investigar, minuciosamente, os aspectos característicos das petições iniciais, no que diz respeito aos três pilares do gênero.

Ribeiro (2010) afirma que "[...] através da análise dos gêneros que circulam em um determinado grupo social, é possível reconhecer a identidade desse grupo face às crenças, às expectativas, às frustrações, às peculiaridades dos sujeitos que compõem tal grupo social” (RIBEIRO, 2010, p. 62). Isso ocorre porque as esferas de atividade humana às quais os gêneros pertencem são fruto da interação, que é permeada por valores ideológicos. Assim, o estudo dos gêneros presentes em um determinado grupo social demonstrará, de algum modo, esses valores.

Dessa maneira, ao analisarmos o gênero Petição Inicial, estamos contribuindo para reconhecer a identidade da esfera jurídica, ou seja, dessa esfera de atividade humana e de comunicação verbal que se mostra tão importante para a construção de uma sociedade mais digna e acessível a todos, uma vez que, por meio desse gênero, discutimos questões como o estilo dos gêneros jurídicos, as

2Em alguns procedimentos processuais, a petição inicial poderá ser oral. Como exemplo disso, temos os procedimentos que ocorrem no âmbito dos Juizados Especiais Cíveis - Lei n. 9.099/1995. 
características desse estilo, os aspectos socioideológicos norteadores dos pilares dos gêneros jurídicos, dentre outras. É o resultado dessa investigação que apresentamos a seguir.

\section{DETALHANDO O GÊNERO PETIÇÃO INICIAL}

Vejamos, a seguir, as análises e os resultados obtidos em relação ao conteúdo temático do gênero petição inicial. Em seguida, veremos a estrutura composicional e, posteriormente, o estilo.

\subsection{O CONTEÚDO TEMÁTICO}

A petição inicial, como já vimos, é o instrumento através do qual o cidadão se vale para ingressar com uma ação na Justiça, a fim de resolver um conflito jurídico, iniciando, desse modo, um processo judicial. Enquanto elemento constituinte de um processo judicial cível, a petição inicial seguirá os trâmites do CPC - que define, dentre tantos outros elementos, os participantes desse processo judicial. Esses participantes detêm elevada importância no estudo desse gênero, já que eles são os sujeitos participantes da cena enunciativa. Nas palavras de Prado, Pereira e Pereira (2016, p. 07), “[...] o papel dos sujeitos envolvidos na cena enunciativa é um dos elementos contemplados pelo conteúdo temático [...]”. Logo, saber qual a função de cada indivíduo que se faz presente no contexto interacional da petição inicial é de grande relevância para conhecermos esse pilar, uma vez que eles são os locutores presentes na enunciação.

Assim, é preciso dizer que a relação jurídico-processual que a petição inicial integra é formada pelas partes (autor e réu - que são parciais) e pelo magistrado (o juiz-Estatal - que é imparcial). O autor da ação processual é aquele que protocolará a petição inicial em seu nome, por meio do seu advogado (profissional que o representará em juízo, tendo em vista sua capacidade postulatória atribuída por lei). O advogado, representante do autor, buscará obter uma decisão final favorável no processo. Essa decisão estará contida na sentença; porém, poderá haver recurso para instância superior. Isso ocorre porque, caso qualquer uma das partes não concorde com a decisão da sentença, poderá entrar com recursos até que se esgotem as suas possibilidades. Logo, não havendo mais o que se fazer pela via recursal, a decisão transitará em julgado, formando a chamada coisa julgada material - aquela para a qual não cabe mais recurso. Já o réu é o indivíduo contra quem se propõe a ação processual, ou seja, aquele contra quem as alegações da petição inicial versarão, indicando que o mesmo, em uma relação factual com o autor, causou a ele um dano (dano esse que pode ser das mais diversas formas; todavia, quando se tratar de um ilícito criminal ou trabalhista, vimos que eles serão resolvidos na seara do direito processual penal ou trabalhista). Dessa forma, cabe ao autor ingressar na Justiça para requerer/solicitar/pedir a reparação do seu direito supostamente lesado.

No processo judicial cível de procedimento comum do qual estamos tratando aqui, a figura do advogado é preponderante, pois, sem ele, as partes processuais (autor e réu) não podem fazer uso da ação judicial. Em outras palavras, não podem fazer uso do processo. Assim, só é possível ingressar na Justiça para pleitear um direito, bem como se defender de uma ação judicial que tramite por meio do procedimento comum, que é o padrão, por intermédio da figura de um advogado legalmente constituído. Na petição inicial, os sujeitos que participam mais diretamente da enunciação realizada por meio do gênero (advogados das partes e juiz-estatal) são todos da área jurídica. Nesse sentido, o conteúdo temático da petição inicial é determinado pela esfera jurídica, ou seja, pelos códigos de leis processuais e materiais. Esses códigos dividem as tarefas dos participantes diretos da enunciação e, assim, determinam, parcialmente, o que o autor (locutor) da petição inicial poderá ou não nela dizer, como ato regulador.

Entretanto, como vimos em Bakhtin (2011), gêneros são tipos relativamente estáveis de enunciados, de modo que é possível que o falante apareça nele. Como se trata de um gênero que está determinado por um conjunto de regras processuais, o conteúdo temático é ainda mais padronizado na petição inicial, e é possível prever parcialmente, e também de forma bastante padronizada, as respostas dos interlocutores (o direito processual também determina como o réu responderá à petição inicial, fazendo uso de outro gênero denominado "Contestação"). Nesse sentido, as funções estabelecidas pelos códigos jurídicos aos locutores e interlocutores do gênero aqui investigado nos permitem conhecer um pouco mais do seu conteúdo temático. 
Os participantes diretos da enunciação criada pela petição inicial são os advogados das partes (do autor e do réu) e o magistrado; desse modo, devemos assimilar que todos eles são "juristas”. Essa característica desses sujeitos presentes na enunciação da petição inicial faz com que eles tenham proficiência para escrevê-la e compreendê-la, uma vez que têm contato frequente com os códigos de lei que a regulam. Além do mais, tais sujeitos foram preparados durante anos para a realização dessa tarefa; logo, estão aptos a fazerem uso do gênero com ampla familiaridade com seu conteúdo básico - temático.

É preciso lembrar que a petição inicial é um elemento do direito processual judicial, fruto do Estado de Direito e, hoje, do Estado Democrático de Direito, portanto, busca-se essencialmente a garantia do Princípio da Segurança Jurídica. Esse princípio visa garantir a estabilidade das relações jurídicas, portanto, objetiva evitar a instabilidade em relação aos direitos dos cidadãos, por meio de leis escritas e sólidas, dividindo poderes e buscando estabelecer claramente as funções de cada um. É por tal fato que a individualidade se mostra como de difícil percepção nos gêneros jurídicos e também em seu conteúdo temático.

Vejamos, a seguir, exatamente, o momento em que os sujeitos participantes da enunciação aparecem definidos pelo gênero.

Excelentíssima Senhora Doutora Juíza de Direito da 1 a Vara da Fazenda Pública da Comarca de Vitória da Conquista, Estado da Bahia:

M. J. A, brasileira, maior, casada, professora, portadora da cédula de identidade RG no XX, SSP - Ba e do CPF XX, residente de domiciliada na Rua XX, n XX, Bairro XX, em Vitória da Conquista, Bahia, por seus in fine assinados procuradores N. P. R. e J. T. D, brasileiros, maiores, casados, Advogados inscritos na OAB/BA respectivamente sob os n. ${ }^{\circ} \mathrm{S} X X$ e XX, com escritório profissional na Rua XX, nº XX, Bairro XX, em Vitória da Conquista, Bahia, vem respeitosamente, requerer como de fato requer, a presente Ação de Obrigação de Não Fazer com pedido de Tutela provisória contra o Estado da Bahia, pessoa jurídica de direito público interno,

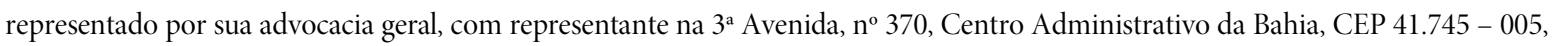
Salvador, Bahia, tendo em vista os relevantes motivos de fato e de direito, expostos a seguir:

Excerto 1: Endereçamento e qualificação das partes em uma petição inicial Fonte: banco de dados das pesquisadoras

Nesse fragmento, notamos as figuras preponderantes para a enunciação proposta pelo gênero: a autora representada por seus advogados, a juíza competente para a causa em questão e o réu (o Estado da Bahia), também representado por seu advogado (a advocacia geral, representada pelo procurador geral do Estado da Bahia que, neste caso, é o setor jurídico responsável pela defesa jurídica do estado). Nesse caso, está sendo requerido que o estado da Bahia não exonere a autora do cargo de professora, que ela exerce no âmbito da Secretaria de Educação, tendo em vista processo administrativo que já havia sido instaurado contra ela, de maneira, supostamente, injusta.

No plano jurídico, o conteúdo temático de cada gênero é norteado, de modo geral, pelos princípios gerais de direito como um todo, estabelecidos na Constituição Federal e também nos códigos infraconstitucionais, como é o caso do Código Civil, por exemplo. Cada caso específico dirá respeito a um ramo do direito material. O caso acima versa sobre o Direito Administrativo, cujo objetivo é "[...] tratar de princípios e regras que disciplinam a função administrativa e que abrange entes, órgãos, agentes e atividades desempenhadas pela Administração Pública na consecução do interesse público[...]” (NOHARA, 2014, p. 06). Assim, é esse ramo do direito material que fundamentará juridicamente, nesse caso, o pedido a ser feito na petição inicial, demonstrando que os fatos narrados pelo autor violam tal especialidade jurídica (o direito administrativo).

Ademais, princípios constitucionais, como os intitulados "ampla defesa" e "contraditório", não podem deixar de ser mencionados aqui, posto que eles fundamentam todas as relações jurídico-processuais. Esses princípios significam que as partes têm o direito de saber o que está acontecendo no processo e se manifestar. Os princípios da ampla defesa e do contraditório se completam, uma vez 
que não adianta saber o que está acontecendo e não poder se manifestar, de modo que também não faz sentido poder se manifestar e não saber o que está acontecendo.

Com isso, é possível perceber que os princípios da ampla defesa e do contraditório marcam papéis, especialmente em relação ao réu, no que se refere ao projeto enunciativo do gênero Petição Inicial, já que deixa frisado o direito do réu de se defender do que está sendo postulado na petição inicial, sob pena de anulação de todo o processo. É por esse motivo que, ao receber a petição inicial, o magistrado mandará citar o réu para que ele se defenda; "citar" significa notificá-lo para que ele saiba que está sendo processado e providencie sua defesa. Cada petição inicial, ao buscar a tutela de bens protegidos pelo direito, o fará com base no direito, seja ele material ou processual, em seus valores e formas de enxergar o objeto do discurso em questão. Portanto, o direito ou domínio jurídico circunscreve o conteúdo dizível no gênero petição inicial.

\subsection{A ESTRUTURA COMPOSICIONAL}

No que se refere à estrutura composicional, como já mencionamos, a petição inicial tem seus requisitos fundamentais e indispensáveis elencados no artigo 319 do CPC. Esses requisitos, já descritos acima, sustentam e ordenam a estrutura composicional do gênero que estamos analisando.

Os pilares formam um todo inseparável que culmina na enunciação objetivada pelo projeto enunciativo de gênero. Assim ocorre, também, com a petição inicial: a sua estrutura composicional forma uma realidade entrelaçada com o conteúdo temático e com seu o estilo. Segundo Ribeiro (2010, p. 61), a estrutura composicional “[...] trata-se, pois, da forma de dizer o dizível (conteúdo temático), diante da seleção dos recursos lexicais, fraseológicos e gramaticais da língua (estilo)”. Essa forma de dizer o dizível, na petição inicial, se dá pelo respeito aos elementos básicos e indispensáveis estabelecidos em lei, sem os quais a petição inicial poderá ser indeferida, ou seja, não aceita pelo seu destinatário.

No curso da interação verbal, dialógica e ideológica construída ao longo da história, a estrutura composicional da petição inicial foi ganhando a forma que tem hoje. Como veremos, as possibilidades de aparecimento da individualidade, nesta estrutura, são pequenas, uma vez que a esfera jurídica é marcada pelos regramentos rígidos próprios dos valores ideológicos que demarcam essa esfera. Para chegarmos a essa estrutura básica do gênero, observamos 25 modelos de petições iniciais de advogados diferentes. Vejamos o primeiro elemento estrutural a aparecer no gênero Petição Inicial: o endereçamento.

\section{EXCELENTÍSSIMO (A) SENHOR (A) DOUTOR (A) JUIZ (A) DE DIREITO DA VARA CÍVEL/FAZENDA PÚBLICA DA}

COMARCA DE IPIAÚ, ESTADO DA BAHIA

Excerto 2: Endereçamento em uma petição inicial

Fonte: banco de dados das pesquisadoras

Acima, temos o chamado endereçamento da Petição Inicial, que é o seu vocativo. O endereçamento é elemento indispensável para o correto protocolamento da petição inicial, uma vez que, sendo direcionada ao juízo (órgão do Poder Judiciário) não competente para julgar a causa que ela (petição inicial) propõe, a petição inicial será indeferida. No entanto, é preciso lembrar, como já mencionamos no segundo capítulo, que a desobediência a alguns requisitos essenciais poderá ser sanada. Isso significa que o magistrado concederá ao autor a chance de emendá-la, ou seja, corrigi-la, em um prazo determinado, qual seja: 15 dias. Vale dizer, também, que, não sendo corrigida a irregularidade, a petição inicial, de fato, será indeferida.

A seguir, o segundo elemento estrutural da petição inicial: a qualificação das partes. 
T. A. P, brasileira, solteira, enfermeira, portadora da cédula de identidade RG $n^{\circ}$ XX SSP/BA, inscrita no CPF sob o nº XX, e-mail: $\mathrm{XX}$, residente e domiciliada na rua XX, ${ }^{\circ} \mathrm{XX}$, bairro XX, Jequié/Bahia, por meio de sua advogada que ao final subscreve, com procuração anexa (doc. 1) e endereço profissional na XX, Praça XX, nº XX, Vitória da Conquista/BA, onde recebe todas as notificações e intimações, vem mui respeitosamente perante Vossa Excelência propor a presente AÇÃO DE RESOLUÇÃO CONTRATUAL COM RESTITUIÇÃO INTEGRAL DAS PARCELAS PAGAS C/C DANOS MORAIS E MATERIAIS, COM PEDIDO DE TUTELA DE URGÊNCIA CAUTELAR em face de J. T.O, brasileiro, autônomo, solteiro, portador da cédula de identidade RG $\mathrm{n}^{\circ} \mathrm{XX}$ SSP/BA, inscrito no CPF sob o $\mathrm{n}^{\circ} \mathrm{XX}$, residente na rua XX, $\mathrm{n}^{\circ} \mathrm{XX}$, Bairro XX, bairro XX, Jequié/Bahia, pelos fatos e fundamentos jurídicos que passa a seguir expor:

Excerto 3: Qualificação das partes em uma petição inicial Fonte: banco de dados das pesquisadoras

Essa seção é indispensável para que a petição inicial seja recebida e alcance o fim almejado, pois, sem a correta individualização das partes do processo, não será possível que a ação siga seu curso normal. Individualizar as partes significa deixar claro quem é o autor e quem é o réu da ação proposta por intermédio da petição inicial. É necessário apresentar todos os pontos elencados no excerto acima para a completa caracterização desses indivíduos. Ao deixar de apresentar algum dos itens necessários à qualificação, o juiz pedirá ao autor que emende a petição inicial, como vimos, podendo, então, o autor consertá-la. Caso não o faça, a petição inicial será indeferida. Como o autor é, obrigatoriamente, representado por um advogado(a) e a petição inicial é proposta pelo autor da ação judicial, seu advogado é qualificado nesse momento enquanto seu representante. O advogado não é parte no processo, mas apenas representante das partes. Nesse momento de qualificação, também se costuma apresentar o nome da ação que se propõe por meio da petição inicial. Esse nome está relacionado ao ramo do direito material a que o bem tutelado está relacionado, bem como diz respeito, também, ao tipo de direito em questão na petição inicial. Por exemplo, no caso acima, o Direito Civil prevê a possibilidade de resolução contratual quando ocorre inadimplemento culposo ou fortuito; quando há descumprimento do contrato, ele deve ser tecnicamente resolvido. É por isso que é possível ingressar com uma ação na Justiça e chamá-la de 'ação de resolução contratual'.

O terceiro elemento estrutural e obrigatório de uma petição inicial é a apresentação dos fatos. Vejamos:

\section{DOS FATOS}

01.1. A autora é ex-servidora pública municipal de Candiba, aposentada, sendo que exercia o cargo de professora na rede de ensino público, tendo trabalhado para a municipalidade desde o ano de 1987, conforme faz prova a anotação em sua CTPS, cuja cópia segue anexa. Se aposentou, sendo o seu último mês de trabalho, o mês de Março do presente ano. Recebeu como último estipêndio o montante de $\mathrm{R} \$ 1.447,77$ (mil quatrocentos e quarenta e sete reais e setenta e sete centavos).

01.2. Em 1992 passou a vigorar no Município de Candiba, estando vigente até os dias atuais, a Lei no 29, de 06 de Dezembro de 1991. Tal Lei versa acerca do Estatuto do Servidor Público do Município de Candiba.

01.3. Desde a vigência até o término do seu contrato de trabalho, a Autora adquiriu o direito a 04 licenças prêmios, visto que laborou por mais de 23 (vinte e três) anos sob a égide da Lei que estabeleceu tal benefício. Porém, esta gozou apenas de uma licença prêmio, não tendo sido convertida em pecúnia o período restante ao qual teria direito.

Excerto 4: Apresentação dos fatos em uma petição

Fonte: banco de dados das pesquisadoras 
Acima, o escrevente apresentou os fatos que culminaram na suposta violação de um direito da autora da petição inicial, qual seja: $\mathrm{O}$ direito a três licenças-prêmio não usufruídas durante seu período de trabalho. O objetivo dos fatos é mostrar ao destinatário da petição inicial, ou seja, ao magistrado, a situação fática causadora do pedido a ser feito. Os fatos formam juntamente com os fundamentos jurídicos - que veremos a seguir - a chamada causa pretendi, isto é, a causa de pedir da petição inicial. Assim, os fatos são indispensáveis e a ausência deles gera indeferimento da petição inicial sem direito à emenda.

Apresentamos, a seguir, a quarta exigência composicional de uma petição inicial, chamada fundamentos jurídicos do pedido.

\section{DOS DIREITOS}

02.1. Conforme explanado nos fatos, à Autora lhe assiste razão a presente demanda, uma vez que, conforme a própria legislação municipal, colacionada aos autos, esta deveria, por direito, ter gozado durante seu período de labor de três licenças-prêmios não concedidas.

02.2. Vejamos, ipsis litteris, o que ordena o artigo 102 da Lei n 29, de 06 de Dezembro de 1991: "Art. 102. Após cada quinquênio ininterrupto de exercício, o funcionário efetivo fará jus a 3 (três) meses de licença-prêmio com a remuneração do cargo efetivo".

02.3. Perceba, Vossa Excelência, que o direito à Licença-Prêmio é cristalino e indubitável, não persistindo quaisquer interpretações dúbias acerca do instituto criado pela legislação municipal.

02.4. Mais adiante, o artigo 105 do mesmo diploma legal, estabelece que "O requerimento do servidor a licença-prêmio poderá ser convertido em dinheiro".

02.5. Ou seja, a própria legislação estabelece a possibilidade de ser feita a conversão em pecúnia do valor devido.

02.6. Ademais, em razão da sua aposentadoria, é óbvio que a Autora não pode mais gozar da licença-prêmio, mas apenas ser indenizada por não ter usufruído de tal benefício no tempo correto.

$\cdots$

Excerto 5: Fundamentos jurídicos do pedido em uma petição inicial

Fonte: banco de dados das pesquisadoras

O fundamento jurídico do pedido é a apresentação dos dispositivos do direito que justificam a solicitação feita na petição inicial. Como vimos no parágrafo anterior, os fatos e os fundamentos jurídicos do pedido formam aquilo que se chama, no âmbito jurídico, de causa de pedir, ou seja, é o porquê do pedido. A causa de pedir se constitui da narrativa dos fatos alegados pelo autor e do enquadramento dessa narrativa em uma categoria jurídico-material. Como ilustração, podemos mencionar que, caso alguém sofra uma lesão de cunho moral que tenha sido fruto de um erro médico, tal pessoa poderá ingressar na Justiça, a fim de pedir reparação pelo dano moral e/ou material; assim, deverá narrar os fatos que geraram o dano e apresentar os fundamentos jurídicos que mostram que o fato é um ilícito jurídico, isto é, viola o ordenamento jurídico, gerando o direito à reparação; no caso em questão, o direito uma indenização. Esses dois elementos, juntos, justificarão o pedido a ser feito pela ação proposta por meio da petição inicial, constituindo a chamada causa de pedir.

No fragmento acima, o escrevente enquadra os fatos, por ele narrado na seção anterior, em uma categoria jurídico-material. Nesse caso, são mostrados os artigos 102 e105 da Lei n 29, de 06 de dezembro de 1991, que instituiu o Estatuto do Servidor Público do Município de Candiba. Os artigos apresentam o fundamento legal para que a autora possa postular seu pedido, qual seja: a conversão das licenças-prêmio não gozadas em dinheiro, perante o órgão judicial competente - já que provaria que o direito alegado está previsto em legislação. Assim, o escrevente apresentará, neste momento da estrutura composicional da petição inicial, os dispositivos de lei que mostram que os fatos anteriormente explanados configuram violação de direito, o que justificará seu pedido feito no final. Vejamos, abaixo, a apresentação do pedido com suas especificações. 


\section{- DOS PEDIDOS}

Ante todo o exposto, requer:

a) A citação da parte ré, para que conteste a presente ação, sob pena de sofrer os efeitos decorrentes da revelia;

b) Os benefícios da justiça gratuita, nos termos da lei;

c) A concessão da tutela cautelar de urgência, já que preenchidos seus requisitos legais, no sentido de arrestar contas bancárias do réu, na falta de saldo positivos dessas, bens móveis, passíveis de garantir futura execução, dispensando-se a prestação de caução. Ademais, a proibição de venda dos imóveis localizados na Rua XXXXXX, Lote XX, Quadra XX, bairro XXXX, Jequié/BA, matrícula XXXX, objeto do processo de adjudicação compulsória nº XXXXX que tramita na $3^{\text {a }}$ Vara Cível da Comarca de Jequié.

d) A condenação da parte ré a restituição integral das parcelas pagas, qual seja, $\mathrm{R} \$ 61.747,00$ (sessenta e um mil setecentos e quarenta e sete reais), acrescido de correção monetária e juros legais.

e) Seja o réu condenado ao pagamento da indenização por danos materiais no valor de R \$5.200,00 (cinco mil e duzentos reais), levando em consideração aluguéis pagos durante o período compreendido entre agosto de 2016 até a presente data, devendo ser corrigido monetariamente e acrescido de juros legais até a data do efetivo pagamento.

f) A condenação da parte ré ao pagamento de indenização por danos morais no valor de $\mathrm{R} \$ 50.000,00$ (cinquenta mil reais).

g) Protesta provar o alegado por todos os meios de prova em direito admitidos, especialmente pelos documentos juntados, da oitiva de testemunhas, e do depoimento pessoal das partes, sem prejuízo de outras provas eventualmente necessárias.

Excerto 6: Pedido com suas especificações em uma petição inicial

Fonte: banco de dados das pesquisadoras.

Nesse requisito, o escrevente solicitará, especificamente, o que ele pretende com a petição inicial. No caso acima, temos diversos pedidos sendo feitos, além do pedido principal. São eles: pede-se a citação da parte ré para que conteste a ação sob pena de revelia, isto é, que a parte contrária seja notificada para que se defenda do que está sendo alegado na petição inicial, sob pena de sofrer os efeitos jurídicos decorrentes do seu silêncio processual; pede-se, também, que o autor goze dos benefícios da justiça gratuita, ou seja, não precise arcar com as custas processuais, tendo em vista sua carência financeira; além disso, pede-se a concessão de tutela de urgência cautelar, isto é, que sejam tomadas medidas para que se garanta o direito almejado e solicitado na petição inicial, ao final do processo, apreendendo bens do réu para que ele não se desfaça dos mesmos; há também o pedido de condenação do réu à devolução de parcelas já pagas referentes a um contrato de compra e venda de uma casa, tendo em vista o não cumprimento do referido contrato pelo réu, o que suscitaria a possibilidade de resolução do mesmo, isto é, dissolução do contrato em caso de inadimplemento fortuito ou culposo; pede-se uma indenização pelos danos materiais sofridos pela autora, com base nos aluguéis pagos no período em que a obra já deveria estar pronta; foi solicitada, ainda, outra indenização por danos morais, com base nos abalos emocionais sofridos pela requerente, decorridos dos fatos em questão. O pedido principal da petição inicial, ou seja, o motivo pela qual a petição inicial existe e foi elaborada é o mais importante pedido a ser feito, no caso acima esse pedido está contido nas letras "d", "e" e "f". Porém, é necessário dizer que, como vimos no excerto aqui analisado, existem outros pedidos a serem elaborados para que o curso/trâmite processual alcance seu fim almejado.

O sexto requisito estrutural do gênero é o valor da causa. Vejamos um exemplo dele.

Dá-se à causa o valor da causa R $\$ 116.947,00$ (cento e dezesseis mil novecentos e quarenta e sete reais).

Excerto 7: Apresentação do valor da causa em uma petição inicial

Fonte: banco de dados das pesquisadoras 
O valor da causa é requisito fundamental à estrutura composicional do gênero, não podendo o escrevente deixar de introduzi-lo no texto da petição inicial. Ainda que a causa não tenha um valor estimável é preciso atribuir algum valor, mesmo que seja simbólico.

O sétimo componente diz respeito ao local, juntamente com a data, nos quais a Petição Inicial se circunscreve.

\begin{tabular}{|c|}
\hline Nestes termos, pede deferimento \\
Jequié, 21 de março de 2017. \\
\hline
\end{tabular}

Excerto 8: Local e data nos quais o escrevente elabora a petição inicial

Fonte: banco de dados das pesquisadoras

O local e a data não estão previstos como requisito estabelecido no artigo 319 do CPC, porém são fundamentais. Apesar de institutos jurídicos como a prescrição serem determinados pela data de protocolamento da petição inicial no órgão competente, não se elabora um documento sem data e local.

Além de tudo isso, é preciso que, ao final, conste no texto do gênero a assinatura do advogado representante do autor e também seu número de inscrição na Ordem dos Advogados do Brasil (OAB). Observemos:

\begin{tabular}{|c|}
\hline $\mathrm{XXXXXX}$ \\
OAB/BA XX. XXX
\end{tabular}

Excerto 9: Assinatura do advogado e do seu número de inscrição na $\mathrm{OAB}$

Fonte: banco de dados das pesquisadoras

Esse requisito também não está previsto no artigo 319 da lei do CPC, mas há a necessidade de assinatura do documento, sem a qual ele não terá validade, uma vez que o advogado é o responsável pela petição inicial em juízo; assim, ainda que junto à petição inicial seja anexado o instrumento de procuração no qual o autor da ação judicial atribui ao advogado poderes para representá-lo no processo em questão, é preciso que este assine a petição inicial, provando que esse documento é de sua autoria.

Esses oito requisitos aqui apresentados, quais sejam: 1) O juízo a que é dirigida; 2) Os nomes, os prenomes, o estado civil, a existência de união estável, a profissão, o número de inscrição no Cadastro de Pessoas Físicas ou no Cadastro Nacional da Pessoa Jurídica, o endereço eletrônico, o domicílio e a residência do autor e do réu; 3) O fato; 4) Os fundamentos jurídicos do pedido; 5) O pedido com as suas especificações; 6) O valor da causa; 7) O local e a data; 8) A assinatura do advogado (representante do autor) são os requisitos básicos e obrigatórios observados em vários modelos de petição inicial do processo judicial cível de procedimento comum, segundo o novo CPC, sem os quais a petição inicial poderá ser recusada pelo seu destinatário. Portanto, podemos perceber que, apesar de o CPC enumerar sete requisitos, na verdade visualizamos o aparecimento de oito. Isso porque os fatos e fundamentos jurídicos estão previstos no mesmo inciso três do artigo 319 dessa lei, ou seja, apesar de estarem juntos, aparecem separados sempre. Além do mais, o local e a data não estão previstos, porém são fundamentais. Também há a necessidade de assinatura do documento.

Ademais, o inciso VII do artigo 319 do CPC, que se refere à necessidade de o autor fazer referência sobre sua opção ou não pela audiência de conciliação ou de mediação, aparece normalmente dentro da seção dos pedidos; todavia, alguns escreventes abrem uma seção para isso. Também, apesar de o CPC fazer expressa referência a essa necessidade, caso o autor não apresente tal elemento, não será causa de indeferimento da petição inicial, apenas o magistrado fará a interpretação de que o autor está de acordo com a realização da audiência.

Em relação ao inciso VI do artigo 319, que pede a indicação das provas com que o autor pretende demonstrar a verdade dos fatos alegados, não há normalmente uma seção específica para esse item, uma vez que tais provas são anexadas, como documentos, na petição inicial e entregues no dia do seu protocolamento, além de serem indicadas ao longo da narrativa e argumentação dos fatos e fundamentos jurídicos; porém, em alguns casos, notamos que alguns escreventes fazem referência às provas em seção específica 
para isso. É indispensável a menção às provas. Ademais, em algumas petições iniciais, o escrevente poderá fazer uso do instituto jurídico da tutela provisória, que não aparece em todas as petições, mas só em casos de urgência ou de evidência. Isso pode ser feito também dentro da seção dos fundamentos jurídicos, pois se trata do enquadramento dos fatos numa categoria jurídica merecedora de urgência e/ou evidência; portanto, trata-se de fundamento jurídico do pedido. A tutela provisória é uma decisão do autor, não é um requisito para a aceitabilidade da petição inicial; ela, quando caracterizada como urgente, tem prioridade de tramitação processual. Em alguns casos, também é possível se fazer o pedido de Justiça gratuita, caso o autor não tenha condições de pagar as custas processuais sem colocar em risco seu sustento. Alguns escreventes abrem uma seção específica para isso, mas também não é obrigatório; portanto pode ser feito na seção dos pedidos.

\subsection{O ESTILO}

O estilo do gênero Petição Inicial e dos gêneros jurídicos, em geral, é bastante característico, posto que reflete, dentre outros aspectos, um vocabulário bastante diferente do utilizado no cotidiano da maioria das pessoas. Esse distanciamento mostra-se não apenas em relação às questões lexicais, mas também fraseológicas e gramaticais da língua. Vale ratificar que o estilo de um gênero, assim como os demais pilares, é definido pela esfera de atividade humana na qual o gênero se circunscreve, ou seja, está inserido. Logo, o vocabulário (léxico) e também as questões fraseológicas e gramaticais são bastante peculiares no domínio linguístico-jurídico e, assim também, no gênero Petição Inicial; na verdade, tais peculiaridades apenas refletem as construções sociais da esfera da qual fazem parte.

Tradicionalmente, a esfera jurídica é marcada pelo rebuscamento linguístico, fruto das interações construídas pelos seus participantes. Essa esfera social é, historicamente, mais elitizada, pois, nela, o uso da língua padrão e rituais de formalidade são elementos "obrigatórios". Além disso, há um grande "apego" a expressões, muitas vezes, em desuso na linguagem atual. Tudo isso justificaria as características do estilo dos seus gêneros discursivos. Além desses fatos, poderíamos a eles atrelar a questão do nosso Direito ter suas bases no Direito Romano, o que explicaria o uso de tantas expressões em Latim nos textos jurídicos. Esse caráter rebuscado dos gêneros jurídicos tem raiz na ordem 'modelada pela coletividade', isto é, nas práticas sócio-históricas que perpassam todos os discursos por meio da interação dialógica, pautando e sustentando os enunciados e, assim, os gêneros do discurso, conforme a ideologia que sustenta cada esfera. No âmbito jurídico, isso se apresenta de forma bastante forte, posto que se trata de um discurso pautado em leis e na burocracia estatal.

Vimos em Bakhtin que o estilo é observado sob dois prismas: o individual (que é resultante da singularidade do sujeito enunciador) e o estilo do gênero (fruto da convergência dos usos linguísticos reiterados em um dado contexto enunciativo - ou seja, fruto da coletividade). Na esfera jurídica, o estilo do gênero tende a ser preponderante e bastante estabilizado, dando pouco espaço para o indivíduo aparecer, ou seja, o estilo do gênero se sobrepõe ao individual (PRADO; PEREIRA; PEREIRA, 2016). A prevalência do estilo do gênero sobre o individual, no gênero Petição Inicial, é resultado também da esfera de atividade humana na qual o gênero está inserido, ou seja, a jurídica. No plano do Direito, como vimos, devido às questões do conteúdo temático ou da necessidade de se garantir os direitos dos cidadãos com base no princípio da segurança jurídica, até a linguagem (estilo) tende a ser muito técnica e padronizada. Entretanto, vale reafirmar que não sendo os sujeitos da cena enunciativa totalmente assujeitados, há sempre lugar para que os indivíduos mostrem sua individualidade na enunciação; ou seja, há lugar para o estilo individual no gênero Petição Inicial, mas, ele será mais raro. Vejamos, nos excertos, a seguir, como o estilo desse gênero se configura. Iniciemos com fragmentos relativos à narração dos fatos em petições iniciais (Excertos 10 e 11).

A autora, no afã de realizar seu sonho de adquirir sua casa própria, firmou com o réu no dia 11 de fevereiro de 2016 o instrumento particular de compra e venda (doc. 03) no qual ajustaram a forma de pagamento, construção e transferência do imóvel localizado no Lote 15, Quadra 06, Loteamento Parque da Colina, bairro Jequiezinho, Jequié/Bahia.

Excerto 10: Trecho inicial da narração dos fatos em uma petição inicial

Fonte: banco de dados das pesquisadoras 
O Autor foi usuário dos serviços prestados pela Administradora de cartões de crédito, sendo ele titular do cartão registrado sob o número XXX XXXXXXXXX. No ano de 2011, o Autor recebeu do Banco Réu uma cobrança indevida, referente a um parcelamento que não existiu.

\section{Excerto 11: Trecho inicial de narração dos fatos em uma petição inicial}

Fonte: banco de dados das pesquisadoras

Nos fragmentos expostos, é possível notar que há uma tendência a se seguir um padrão. Percebemos essa tendência ao observarmos que a data em que os fatos descritos ocorrem já é apresentada no primeiro parágrafo da exposição dos fatos. Além disso, nos dois excertos, temos o escrevente se referindo ao titular do direito postulado na petição inicial como autor ou autora, o que demonstra a recorrência do uso de expressões similares e técnicas. Também a esse respeito, o indivíduo contra quem se alega os fatos narrados é denominado réu nos dois fragmentos, outro caso de uso de similitude de termos técnicos apenas na seção intitulada "Dos Fatos”. Já vimos que autor é o termo técnico usado para designar a pessoa que solicita (por meio do seu advogado) ao Poder Judiciário (magistrado) a resolução de uma controvérsia jurídica, fazendo, para isso, uso da petição inicial. E réu é aquele contra quem a petição inicial versará.

Vejamos mais exemplos (Excertos 13, 14, 15), agora apontando termos muito usados nos textos jurídicos e que podem ou não refletir rebuscamento, mas que guardam consigo a característica de serem típicos da área.

Em 1992 passou a vigorar no Município de Candiba, estando vigente até os dias atuais, a Lei nº 29, de 06 de Dezembro de 1991. Tal Lei versa acerca do Estatuto do Servidor Público do Município de Candiba.

Excerto 12: Trecho retirado de uma petição inicial para ilustrar o estilo do gênero

Fonte: banco de dados das pesquisadoras

Requer, assim, que seja deferida a conversão das licenças-prêmio não gozadas em pecúnia, com a consequente condenação do Réu ao pagamento das 03 (três) licenças não gozadas, o que equivale a nove vezes a última remuneração percebida, totalizando, assim, o montante de R $13.029,93$ (treze mil e vinte e nove reais e noventa e três centavos), o qual deverá ser corrigido e atualizado monetariamente.

Excerto 13: Trecho retirado de uma petição inicial para ilustrar o estilo do gênero

Fonte: banco de dados das pesquisadoras

Colacionaremos apenas o seguinte julgado do STF, para não mais delongar em matéria já uníssona e inequívoca: (...)

Excerto 14: Trecho retirado de uma petição inicial para ilustrar o estilo do gênero

Fonte: banco de dados das pesquisadoras

Nesses excertos, vemos palavras típicas da seara jurídica, tais como: vigorar, vigente, requer, condenação e julgado. Esses termos são comuns de serem encontrados em exemplares de petições iniciais, de modo que visualizamos sua ocorrência reiteradas vezes. Eles são também mais habituais e compreensíveis à população em geral. Além deles, visualizamos outras palavras como: audiência, requerente (que é uma derivação do verbo requer, já apontado acima), vedado, tutela, requerimento, deferimento, procedente, improcedente, procuração, procurador, alegar, dentre outras, nas quais pode haver maior dificuldade e estranhamento aos leigos. 
Enfim, são muitos vocábulos típicos do mundo jurídico presentes no gênero Petição Inicial e que podem ou não revelar complexidade àquele que não é um profissional da área

Já o excerto 15 representa um exemplo no qual o vocabulário do gênero exibe um alto grau de erudição jurídica, dificultando bastante a apreensão do sentido por um cidadão leigo. Vejamos:

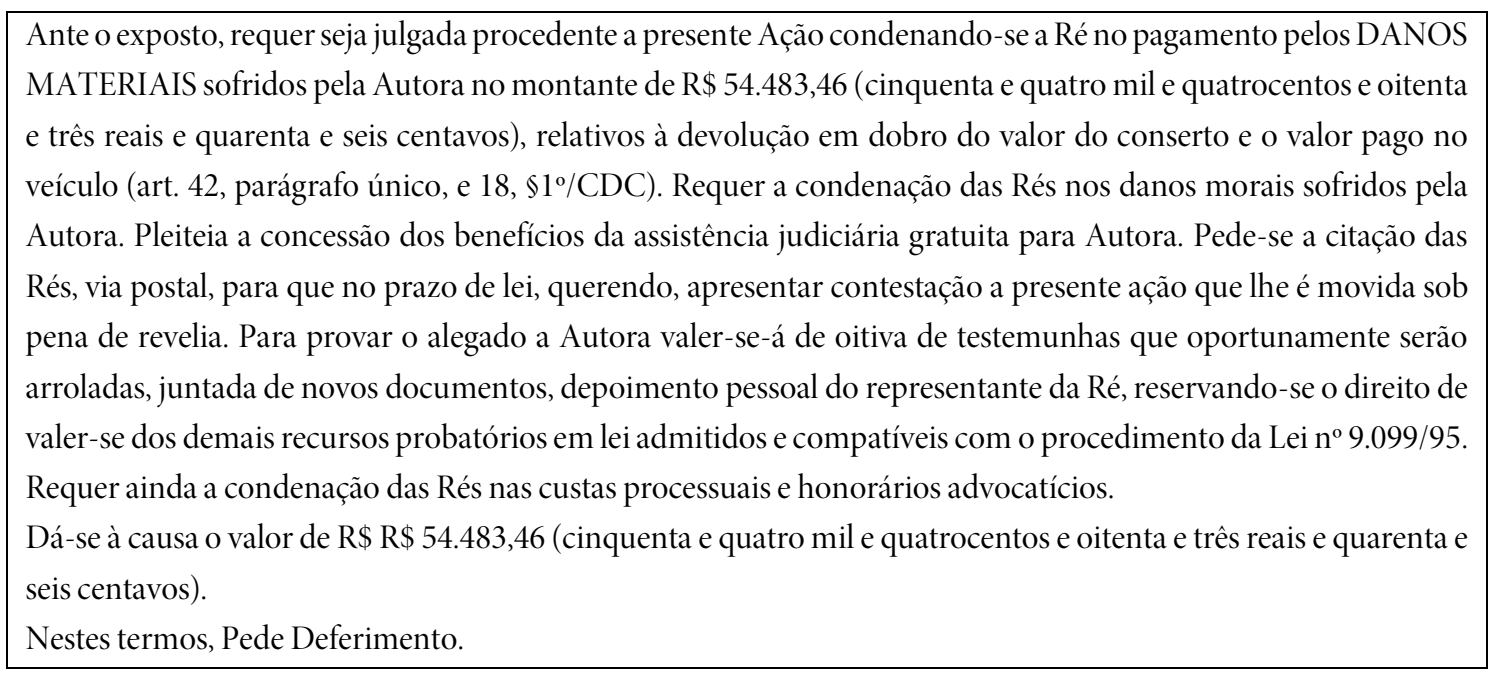

Excerto 15: Trecho retirado de uma petição inicial para ilustrar o estilo do gênero

Fonte: banco de dados das pesquisadoras

Nesse fragmento, vemos o aparecimento de termos muito usados na área jurídica, tais como: ré, autora, danos materiais, danos morais, pleiteia, assistência judiciária gratuita, citação, contestação, revelia, provar, alegado, oitiva, testemunhas, arroladas, juntada dos documentos, depoimento pessoal do representante da ré, recursos probatórios, procedimento, requer, condenação, custas processuais, honorários advocatícios, causa. Nesse excerto, vemos a prevalência do estilo do gênero sobre o estilo individual, posto que as palavras próprias do campo jurídico têm uma ocorrência grande, sobrepondo-se ao estilo individual do escrevente.

Entretanto, o excerto contém palavras que, apesar de refletirem um vocabulário jurídico, são acessíveis ao cidadão leigo como, por exemplo, o termo “depoimento". Porém, há, também, palavras muito usadas nessa área e que são pouco ou nada vistas fora do ramo, como: pleiteia e procedente. Essas palavras servem para ilustrar que existem termos que não são necessariamente técnicos, mas que são próprios do gênero Petição Inicial e dos gêneros jurídicos de um modo geral. Os termos técnicos guardam um significado peculiar à esfera em questão, não podendo ser trocados por outro vocábulo sem incorrer em risco para o sucesso do recebimento da petição inicial, como é o caso de réu, citação, contestação, revelia etc. Esses termos técnicos ou não existem fora do meio jurídico ou quando existem detêm um outro sentido que pode dificultar o correto andamento do trâmite processual, prejudicando aquele que visa alcançar um resultado jurídico-processual positivo. Por certo, na interação advogado/cliente, é possível e necessário que o advogado realize a "tradução" desses termos para que o seu cliente os compreenda.

\section{CONSIDERAÇÕES FINAIS}

Neste artigo, objetivamos, fundamentados na abordagem dialógica de Bakhtin (2011) a respeito dos gêneros discursivos, investigar um gênero que pertence à esfera jurídica: a petição inicial.

Com a investigação proposta, almejávamos contribuir para o processo de contextualização de atividades típicas do trabalho que se realiza na esfera jurídica, especificamente os relacionados ao gênero petição inicial, mostrando como especificidades/regularidades linguísticas (uso de certos tipos de avaliação, tipos de orações, estrutura temática etc.) caracterizam as práticas desenvolvidas pelos profissionais do Direito por meio da linguagem no que diz respeito a esse gênero. 
Acerca do conteúdo temático, vimos que "[...] ele é o tópico que garantirá a ativação de conhecimentos sociais discursivamente construídos [...]" (RIBEIRO, 2010, p. 57). Assim, pontuamos que a petição inicial, na modalidade em que estamos tratando, é um texto escrito, que inicia o processo judicial cível. Nela, o advogado, representante da parte autora, formula seu pedido contra determinada pessoa, narrando os fatos, apresentado artigos de lei a respeito do caso e apresentando provas. Ela é endereçada ao juiz de Direito, que tem o poder de recebê-la ou não.

Em relação à estrutura composicional, como qualquer outro gênero, a petição inicial possui uma arquitetura que lhe é típica. Vimos que a estrutura composicional está relacionada ao "[...] aspecto por assim dizer técnico da realização do gênero, contribuindo para identificá-lo e distingui-lo diante de outros gêneros [...]" (RIBEIRO, 2010, p. 60). Obviamente, como componente de uma concepção enunciativa e dialógica da linguagem, a estrutura composicional dos gêneros é uma estrutura relativamente estabilizada, podendo sofrer interposição dos sujeitos participantes da enunciação. Podemos corroborar tal afirmação nas palavras de Ribeiro (2010), ao salientar que "[...] a despeito do caráter regulador da forma do gênero, há espaço para a expressão do sujeito, visto que ao participar das atividades de linguagem, ele (re)elabora, (re)cria, (re)formula formas de gênero [...]" (RIBEIRO, 2010, p. 60). A petição inicial, por sua vez, possui formas típicas da esfera jurídica, com elementos constitutivos mais rígidos, revelando poucas possibilidades de entradas subjetivas. Em nossas investigações, reconhecemos a seguinte forma estrutural do gênero:

1) O juízo a que é dirigida;2) Os nomes, os prenomes, o estado civil, a existência de união estável, a profissão, o número de inscrição no Cadastro de Pessoas Físicas ou no Cadastro Nacional da Pessoa Jurídica, o endereço eletrônico, o domicílio e a residência do autor e do réu; 3) O fato; 4) Os fundamentos jurídicos do pedido; 5) O pedido com as suas especificações; 6) O valor da causa; 7) O local e a data; 8) A assinatura do advogado.

Sobre seu estilo, vimos que é pouco variável. A petição inicial, apesar de ser um documento público, tende a circular apenas entre os sujeitos envolvidos de forma mais direta na cena enunciativa, que são: quem a escreve (o advogado), a quem é endereçada (o juiz) e o representante legal do réu, o que gera um estilo muito peculiar e burocrático, tendo em vista a preservação da segurança jurídica que marca as relações dessa área.

Uma característica marcante do estilo da petição inicial é a recorrente escolha rebuscada do léxico que é utilizado para textualizá-la. Tais escolhas se justificam se levarmos em consideração que é um advogado quem escreve o documento e o endereçamento é a um juiz de Direito. O vocabulário possui marcas de acordo com a esfera social e econômica do gênero. Tendo em vista que o texto acaba por circular apenas na esfera jurídica, não há a preocupação em torná-lo acessível aos cidadãos leigos ou com baixa escolaridade.

Como constatamos, a área jurídica é também uma esfera discursiva, ou seja, a linguagem aqui também é veiculadora de ideologia e de forma intensa. Nesse caso, a esfera se vale do estilo rebuscado de sua linguagem para restringir seu discurso a um pequeno grupo social. No entanto, não é somente esse léxico "difícil" que torna o discurso jurídico distante da população em geral; há outros instrumentos e toda uma conjuntura de relações de poder/luta de classes que colabora para isso.

Porém, cabe ressaltar que a petição inicial deve ser elaborada de maneira que leigos da esfera jurídica a compreendam. Ou melhor, ela deveria ser produzida especificamente para que o autor e o réu da ação as compreendessem. Entretanto, o rebuscamento é uma barreira entre as pessoas e o Direito, haja vista que a quantidade de termos técnicos e palavras desconhecidas do cotidiano popular impede o entendimento dos textos jurídicos. O próprio réu ou até mesmo o autor da petição inicial (que são os maiores interessados) podem não compreender o texto e o que isso significa para sua vida. Então, o tipo de vocabulário utilizado, as expressões em Latim, o excesso de termos técnicos, antigos, se diminuídos, contribuirão para a facilitação do entendimento dos não profissionais ou não letrados na área, o que os permitirá exercer melhor sua cidadania.

\section{REFERÊNCIAS}

BAKHTIN, M. M. Estética da criação verbal. 4. ed. Trad. P. Bezerra. São Paulo: Martins Fontes, 2003. 
BAKHTIN, M. M. Estética da criação verbal. Introdução e tradução de Paulo Bezerra. 6. ed. São Paulo: Editora WMF Martins Fontes, 2011.

BRANDÃO, F. A história do Direito como disciplina fundamental. Publicado em $1^{\circ}$ de fevereiro de 2010. Disponível em: http://www.ambito-juridico.com.br/site/index.php?n link=revista artigos leitura\&artigo id=7231. Acesso em: 20 nov. 2017.

BRASIL. Presidência de República. Casa Civil. Subchefia para Assuntos Jurídicos. Código de Processo Civil. Disponível em: http://www.planalto.gov.br/ccivil 03/ ato2015-2018/2015/lei/113105.htm.Acesso em: 14 mai. 2017.

DIDIER, F. JR.Curso de Direito Processual Civil.Volume I: 11. ed. Salvador: Editora JusPodivm, 2009.

DIDIER, F. JR.Curso de Direito Processual Civil. 17. ed. Salvador: Ed. Jus Podivm,

2015.

MARINONI, L. G; ARENHART, S; MITIDIERO, D. Novo Código de Processo Civil Comentado. São Paulo: Editora Revista dos Tribunais, 2015.

NOHARA, I. P. Direito Administrativo. 4. ed. São Paulo: Atlas, 2014.

PRADO, A. C. D. R.; PEREIRA, M. H. de M.; PEREIRA, L. C. de M. O gênero denúncia: um estudo da sua estrutura composicional. In: LOUSADA, E. et al.(org.). Diálogos Brasileiros no Estudo de Gêneros textuais/discursivos. 1. ed.. Araraquara: Letraria, 2016, p. 07.

RIBEIRO, P. B. Funcionamento do gênero do discurso. Bakhtiniana, São Paulo, v. 1, n. 3, p. 54-67, 1º sem. 2010.

\section{() (1) $\circledast \Theta$}

